\title{
PENERAPAN PEMBELAJARAN DENGAN PENDEKATAN KETERAMPILAN PROSES SAINS UNTUK MENINGKATKAN HASIL BELAJAR KIMIA SMK NEGERI 3 MATARAM
}

\author{
Henikusniati \\ Magister Pendidikan IPA Universitas Mataram
}

\begin{abstract}
Abstrak
Secara umum penelitian ini bertujuan untuk mengetahui penerapan pembelajaran dengan pendekatan keterampilan proses sains untuk meningkatkan hasil belajar kimia di SMK Negeri 3 Mataram. Populasi dalam penelitian ini adalah seluruh peserta didik program keahlian teknik bangunan kelas XI SMK Negeri 3 Mataram. Subyek penelitian melibatkan dua kelas yaitu kelas eksperimen dan kelas kontrol. Penelitian ini merupakan penelitian quasi eksperimen dengan desain nonequivalent pre-test post-test control group design. Instrumen pengumpulan data berupa soal tes dalam bentuk soal pilihan ganda. Pengujian statistik dengan menggunakan independent sample t-test yang yang sebelumnya diuji normalitas dan uji homogenitas pada taraf signifikan 0,05. Hasil penelitian menunjukkan tidak ada perbedaan peningkatan hasil belajar secara signifikan pada kelas eksperimen dan kelas kontrol.
\end{abstract}

Kata Kunci: keterampilan proses sains, hasil belajar 


\section{PENDAHULUAN}

Pembelajaran kimia sebagai bagian dari pendidikan Ilmu Pengetahuan Alam (IPA) memiliki peranan penting dalam perkembangan Ilmu Pengetahuan dan Teknologi (IPTEK) di Indonesia. Mata pelajaran kimia merupakan salah satu mata pelajaran sains yang diterima siswa di Sekolah Menengah Kejuruan (SMK) dalam paket keahlian teknik bangunan. Bidang studi kimia seharusnya merupakan pelajaran yang menyenangkan, karena berhubungan dengan kehidupan seharihari.

Bidang studi kimia seharusnya pelajaran yang menyenangkan, karena berhubungan dengan kehidupan seharihari. Akan tetapi apa yang diharapkan umumnya berlainan dengan kenyataan. Hal ini dapat terjadi salah satunya adalah dengan penggunaan pendekatan pembelajaran yang kurang tepat oleh guru dalam mengajar. Untuk mengatasi permasalahan tersebut, diperlukan suatu strategi pembelajaran yang efektif dalam pembelajaran kimia. Untuk mengembangkan pelajaran kimia yang relevan dengan proses dan produk yang sehari-hari digunakan oleh masyarakat, dapat diterapkan pembelajaran berbasis literasi sains. Diharapkan dengan penerapan pembelajaran kimia dengan pendekatan keterampilan sains ini, pembelajaran akan menjadi lebih efektif dan lebih menarik, sehingga dapat meningkatkan minat dan perhatian siswa saat belajar kimia dibanding pembelajaran yang dilakukan dengan menggunakan metode konvensional (Ambarsari 2013).

Keterampilan proses itu sendiri merupakan keterampilan melibatkan keterampilan pengetahuan atau intelektual, keterampilan intektual memicu siswa agar dapat memahami materi yang disampaikan oleh guru pada proses kegiatan belajar mengajar. Dalam pelaksanaan kegiatan belajar mengajar kimia, hendaknya menggunakan strategi yang melibatkan siswa aktif dalam belajar baik secara mental, fisik maupun sosial (Yuniastuti, 2013).

Menurut Deta (2013), siswa yang memiliki keterampilan proses tinggi akan mudah dalam melakukan penyelidikan dalam

38 BIOTA: Jurnal Tadris IPA Biologi FITK IAIN Mataram 
metode pembelajarannya. Semua kegiatan inkuiri melibatkan keterampilan proses yang meliputi keterampilan proses dasar, keterampilan pengukuran dan perhitungan, keterampilan perencanaan eksperimen, dan keterampilan mengolah serta menyajikan data.

Tujuan penelitian yang hendak ingin dicapai adalah untuk mengetahui penerapan pembelajaran dengan pendekatan keterampilan proses sains untuk meningkatkan hasil belajar kimia di SMK Negeri 3 Mataram.

\section{METODE PENELITIAN}

Penelitian menggunakan metode eksperimen semu (quasi eksperimen). Populasi penelitian ini adalah Populasi dalam penelitian ini adalah seluruh peserta didik program keahlian teknik bangunan kelas XI SMK Negeri 3 Mataram yang terdistribusi dalam beberapa paket keahlian yang bejumlah 5 kelas antara lain: teknik gambar bangunan ada 2 kelas, teknik konstruksi batu beton 1 kelas, teknik kontruksi kayu 1 kelas, dan teknik survei dan pemetaan1 kelas dengan jumlah siswa 137. Sampel diambil dengan teknik purposive sampling sejumlah dua kelas yaitu kelas eksperimen berjumlah 37 siswa dan kelas kontrol berjumlah 37 siswa. Teknik analisis data adalah Uji $N$ Gain untuk mengetahui peningkatan hasil belajar ranah pengetahuan berdasarkan nilai pre-test dan post-test.

\section{HASIL PENELITIAN}

\section{Analisis Nilai Pre-Test}

Hasil penelitian diperoleh nilai rata-rata pre-test kelas eksperimen adalah 38,00 dan kelas kontrol adalah 32,77. Hal ini menunjukkan bahwa nilai rata-rata pre-test pada siswa kelas eksperimen lebih besar dibandingkan nilai rata-rata siswa kelas kontrol. Analisis data pre-test digunakan untuk melihat tingkat normalitas data dan homogitas data. Apabila data lebih besar dari 
0,05 ( $p>0,05)$ maka data kedua kelas tersebut berdistribusi normal dan berkategori homogen.

\section{Analisis Nilai Post-Test}

Hasil yang diperoleh dari analisis nilai rata-rata post-test kelas eksperimen adalah 66,51 dan kelas kontrol adalah 61,16. Hal ini berarti nilai rata-rata post-test siswa kelas eksperimen lebih tinggi dibandingkan dengan kelas kontrol. Berdasarkan analisis data uji normalitas post-test maka signifikans pada kedua kelas lebih kecil dari $0,05(\mathrm{p}<0,05)$ sehingga data kedua kelas tersebut tidak berdistribusi normal. Sedangkan hasil analisis uji homogenitas sebesar 0,674 yang berarti lebih besar daripada 0,05 ( $p>0,05)$ sehingga data tersebut berkategori homogen.

\section{Analisis Nilai $\mathbf{N}$-Gain}

Analisi nilai $N$-Gain pada kelas eksperimen adalah 0,45 sedangkan pada kelas kontrol adalah 0,42. Menunjukkan bahwa kedua kelas tersebut peningkatan $\mathrm{N}$-Gain berkategori sedang. Uji normalitas dan homogen digunakan untuk melihat tingkat normalitas data dan homogitas data. Hasil data tersebut lebih besar dari 0,05 maka data kedua kelas tersebut berdistribusi normal dan berkategori homogen. Berdasarkan data normal dan homogen maka uji hipotesisnya menggunakan uji-t, hasil adalah lebih besar dari 0,05 ( $p>0,05)$ sehingga dapat dikatakan bahwa tidak ada perbedaan peningkatan secara signifikan hasil belajar antara kelas eksperimen dan kelas kontrol.

\section{PEMBAHASAN}

Apabila dilihat dari hasil pre-test dan post-test, peningkatan hasil belajar kelas eksperimen sebesar 45\%, sedangkan kelas kontrol sebesar 42\%. Hasil tersebut, menunjukkan bahwa ada peningkatan hasil belajar siswa. Hasil penelitian Rahayu (2011), menunjukkan bahwa dengan pendekatan keterampilan proses sains dapat meningkatkan hasil belajar siswa. Hasil yang sama juga ditunjukkan oleh Deta (2013), yaitu dengan penerapan

40 BIOTA: Jurnal Tadris IPA Biologi FITK IAIN Mataram 
pendekatan keterampilan proses sains dapat meningkatkan hasil belajar siswa.

Hasil penelitian menunjukkan bahwa penerapan pembelajaran dengan pendekatan keterampilan proses sains, masih belum bisa meningkatkan hasil belajar siswa SMK secara siginifikan pada taraf yang lebih tinggi. Meskipun beberapa penelitian menunjukkan keterampilan proses sains dapat meningkatkan hasil belajar, pendekatan keterampilan proses sains tidak selalu dapat meningkatkan hasil pembelajaran secara signifikans. Menurut Astuti (2012) hal tersebut dapat disebabkan oleh, latar belakang pendidikan siswa di sekolah, karena siswa SMK tidak terlalu mendalami materi pelajaran disebabkan kimia tidak termasuk dalam ujian nasional. karakteristik pembelajaran di sekolah, mereka menganggap pelajaran yang penting adalah pelajaran praktikum siswa kejuruan yang nantinya berhubungan erat dengan bidang yang mereka tekuni. media pengajaran, pendidikan yang disertai media yang tepat, selain memudahkan siswa dalam mengalami, memahami, mengerti apa yang disampaikan. sumber belajar, siswa tidak memiliki buku pegangan materi kimia, sehingga dalam hal membaca dan mencari informasi masih kurang. faktor persepsi diri siswa sebagai salah satu bagian faktor internal harus diperhatikan karena memiliki pengaruh terhadap hasil belajar siswa.

Keterampilan proses sains dapat tumbuh secara efektif apabila siswa dibiasakan untuk berlatih. Hal ini sesuai dengan hukum latihan (the law of exercise) yang dikemukakan oleh Thorndike dalam Lutfa (2014) bahwa hubungan antara stimulus dan respons akan menjadi kuat apabila sering dilakukan latihan.

\section{KESIMPULAN}

Berdasarkan hasil uji hipotesis yang telah dilakukan dengan menggunakan uji-t ternyata Ho diterima dan Ha ditolak artinya tidak terdapat perbedaan yang signifikan hasil belajar kimia antara siswa kelas eksperimen dengan model pembelajaran pendekatan keterampilan proses sains dan kelas kontrol dengan 
model pembelajaran pendekatan konvensional (secara langsung) pada siswa kelas XI SMK Negeri 3 Mataram.

\section{SARAN}

Keterampilan proses sains perlu dilatihkan pada siswa saat proses pembelajaran agar siswa terbiasa untuk melakukan ketarampilan proses sains. Usntuk dapat melatihkan keterampilan proses sains guru hendaknya memperhatikan instrumen yang digunakan.

\section{DAFTAR PUSTAKA}

Ambarsari, W. Santosa, S. \& Maridi. 2013. Penerapan Pembelajaran Inkuiri Terbimbing Terhadap Keterampilan Proses Sains Dasar pada pelajaran biologi siswa kelas VIII SMP Negeri 7 Surakarta. Solo.

Yuniastuti, E. 2013. Upaya Meningkatkan Keterampilan Proses dan Hasil Belajar Biologi dengan Pendekatan Pembelajaran Jelajah Alam Sekitar pada Siswa Kelas VII SMP Kartika V-1 Balikpapan.

Deta, V.A. Suparmi. \& Widha, S. 2013. Pengaruh Metode Inkuiri Terbimbing dan Proyek, Kreativitas, serta Keterampilan Proses Sains Terhadap Prestasi Belajar Siswa. Surakarta.

Rahayu, E. Susanto, H. \& Yulianti, D. 2011. Pembelajaran Sains dengan Pendekatan Keterampilan Proses untuk Meningkatkan Hasil Belajar dan Kemampuan berpikir Kreatif Siswa. Semarang.

Astuti, R., Sunarno, W., Sudarisman, S. 2012. Pembelajaran IPA dengan Pendekatan Keterampilan Proses Sains Menggunakan Metode Eksperimen Bebas Termodifikasi dan Eksperimen Terbimbing Ditinjau dari Sikap Ilmiah dan Motivasi Belajar Siswa. Surakarta.

Lutfa, A., Sugianto. \& Sulhadi. 2014. Penerapan Model Pembelajaran PBL (Problem Based Learning) untuk Menumbuhkan Keterampilan Proses Sains pada Siswa SMA. Semarang.

42 BIOTA: Jurnal Tadris IPA Biologi FITK IAIN Mataram 